\title{
PENERAPAN MODEL PEMBELAJARAN SNOWBALL THROWING UNTUK MENINGKATKAN KEAKTIFAN MATEMATIS MATERI LINGKARAN PADA SISWA SMP
}

\section{Application of Snowball Throwing Learning Model to Increase Mathematical Activeness Circle Material of Junior High School Students}

\author{
Julia Novitasari $^{1^{*}}$, Heni Pujiastuti ${ }^{2}$ \\ ${ }^{1,2}$ Pendidikan Matematika, FKIP, Universitas Sultan Ageng Tirtayasa \\ Jalan Raya Jakarta Km 4, Panancangan, Cipocok Jaya, Kota Serang, Banten, Indonesia 42124 \\ e-mail:1*jnovitasari92@gmail.com ; 2 henipujiastuti@untirta.ac.id \\ Corresponding author*
}

\begin{abstract}
Abstrak
Keaktifan siswa kelas VIII H SMPN 1 Ciruas semester genap tahun pelajaran 2019/2020 mata pelajaran matematika pada materi lingkaran masih berada pada persentase 59,64\% dari total 33 siswa, sehingga hasil tersebut masih kurang dari persentase yang ditetapkan oleh peneliti yaitu sebesar $65 \%$. Berdasarkan masalah tersebut, maka perlu dilakukannya perbaikan pada model pembelajaran. Penelitian ini bertujuan untuk meningkatkan keaktifan siswa pada mata pelajaran matematika. Metode penelitian ini adalah penelitian tindakan kelas. Obyek penelitian tersebut adalah penerapan model pembelajaran snowball throwing. Penelitian ini dilakukan dalam dua siklus, siklus I terdiri dari satu pertemuan dan siklus II terdiri dari satu pertemuan. Tahapan dalam siklus ini yaitu (1) Perencanaan, (2) Tindakan, (3) Observasi, (4) Refleksi. Teknik pengumpulan data yaitu dengan menggunakan hasil observasi, angket dan dokumentasi. Berdasarkan hasil analisis data yang diperoleh secara deskriptif kuantitatif, bahwa terjadi peningkatan keaktifan siswa dengan persentase keaktifan pada siklus I ke siklus II, yakni siklus I dari hasil observasi peneliti, didapatkan bahwa hasil dari keaktifan siswa yaitu sebesar 45,88\% dan didapatkan dari hasil angket siswa sebesar 59,64\%. Lalu pada siklus II mencapai nilai 67,09\% dari standar keaktifan yang telah ditetapkan peneliti yaitu sebesar $65 \%$. Sehingga didapatkan peningkatan persentase dari siklus I ke siklus II. Maka didapatkan kesimpulan bahwa dengan diterapkannya model pembelajaran snowball throwing pada pembelajaran matematika materi lingkaran pada siswa kelas VIII H SMP Negeri 1 Ciruas terjadi peningkatan keaktifan siswa.
\end{abstract}

Kata Kunci : Keaktifan, Snowball throwing

\begin{abstract}
Student activeness in the class student of VIII H SMPN 1 Ciruas second term 2019/2020 year on mathematics subjects on circle material still in percentage 59,64\% of the total 33 students, so that result less than expected value by researcher which is $65 \%$. Based on these problems, it is necessary to make improvements to the learning model. For that researchers conduct research with the purpose to increase student activity in mathematics. Method of research is classroom action research. The object of the research is the application of the snowball throwing model. This research was conducted in two cycles, cycle I consists of one meeting and cycle II consists of two meetings. Stages in this cycle is (1) Planning, (2) Action, (3) Observer, (4) Reflection. The data collection method used were observation, questionnaires and documentation. Based on the results of data analysis obtained by descriptive quantitative, that an increase in student activity with a percentage of activity in cycle I to cycle II, that is cycle I from the observations of researchers, it was found that the results of student activeness were equal to $45,88 \%$ and obtained from the results of a student questionnaire of 59,64\%. Then on cycle II reaches a value of $67,09 \%$ from the activeness standard set by the researcher which is $65 \%$. So that the percentage in crease can be obtained from the cycle I to cycle II. The conclusion is that by applying the snowball throwing learning model on learning mathematics circle material in class student VIII H SMPN 1 Ciruas an increase in student activity.
\end{abstract}

Keywords: Activeness, Snowball throwing

Submitted: $26^{\text {th }}$ May 2020

Accepted: $12^{\text {th }}$ July 2020

This is an open access article under the $C C-B Y-S A$ license (i) (2) 


\section{PENDAHULUAN}

Seiring dengan perkembangan zaman, pendidikan saat ini bertujuan mempersiapkan peserta didik untuk menghadapi masa yang akan datang. Melalui proses pembelajaran, peserta didik dipersiapkan sedemikian rupa agar mampu menyelesaikan masalah-masalah yang dihadapi dalam kehidupannya. Mempersiapkan peserta didik yang mampu menghadapi masa depan, bukanlah suatu hal yang mudah. Guru sebagai fasilitator dalam proses pembelajaran di sekolah dituntut untuk memberikan pengalaman kepada peserta didik. Salah satu masalah yang dihadapi oleh dunia pendidikan di Indonesia adalah rendahnya tingkat keaktifan peserta didik pada proses pembelajaran, terlebih lagi pada mata pelajaran matematika. Banyak faktor yang mentebabkan hal tersebut, salah satu diantaranya yaitu disebabkan karena proses pembelajaran yang dilakukan oleh guru tidak efektif, tidak menggunakan model-model pembelajaran, serta peserta didik yang sudah menganggap bahwa mata pelajaran matematika adalah pelajaran yang sulit [1]. Dalam proses belajar di sekolah tidak lagi hanya memahami teori-teori, tetapi harus mengalami pengalaman yang nyata. Peserta didik dituntut aktif dalam proses pembelajaran, mampu mengemukakan pendapatpendapatnya, serta mampu memecahkan masalah-masalah yang disajikan oleh guru dalam proses pembelajaran [2].

Salah satu bidang yang berkembang pada zaman moderen ini adalah pada bidang pendidikan [3]. Dalam rangka meningkatkan mutu pendidikan di Indonesia, guru merupakan salah satu ujung tombak yang berperan penting di dunia pendidikan. Dalam memberdayakan sekolah, peranan guru sangat strategis dan bermanfaat untuk mempersiapkan sumber daya manusia yang berkualitas sehingga semua usaha reformasi pendidikan yang diarahkan pada perubahan kualitas akan menempatkan guru sebagai kunci keberhasilan pendidikan [4]. Menurut [5] tujuan belajar secara umum adalah untuk mencapai perubahan dalam tingkah laku orang yang belajar. Oleh karena itu untuk mencapai tujuan belajar, maka guru harus mampu mencari solusi dalam menyelesaikan masalah yang ditimbulkan pada proses pembelajaran di dalam kelas, sehingga guru mencari suatu solusi untuk meningkatkan aktivitas dan prestasi belajar siswa. Proses belajar siswa untuk mendapatkan pengetahuan disebut dengan aktivitas belajar. Aktivitas belajar dapat dilihat dari aktivitas fisik dan mental siswa selama proses pembelajaran. Jika sudah terlibat secara fisik dan mental, maka siswa akan merasakan suasana belajar yang lebih menyenangkan sehingga hasil belajar dapat dimaksimalkan [6].

Pembelajaran merupakan salah satu hal dalam bidang pendidikan yang harus mendapat perhatian penting. Pada kenyataannya, pembelajaran saat ini menunjukkan bahwa masih terdapat berbagai kelemahan yang sering dijumpai dalam pelaksanaan pembelajaran seperti: (1) terdapat banyak kasus penggunaan waktu belajar mengajar yang tidak $100 \%$, (2) terdapat guru yang mengelola pembelajaran tanpa berpandu pada silabus dan RPP yang telah disusun, (3) banyak proses pembelajaran masih berpusat pada guru, dan (4) banyak pembelajaran hanya diarahkan pada pengembangan kemampuan akademik peserta didik saja [7].

Pada umumnya mata pelajaran matematika di sekolah diajarkan oleh guru kepada peserta didik dengan menggunakan cara yang konvensional, dengan proses pembelajaran yang hanya berpusat pada guru dan disampaikan dengan metode ceramah [8]. Akibatnya dalam proses pembelajarannya peserta didik menjadi pasif, merasa jenuh bahkan akan kesulitan dalam memahami konsep matematika secara maksimal [9]. Salah satu cara untuk mengaktifkan belajar peserta didik adalah dengan memberikan berbagai pengalaman belajar yang bermakna yang bermanfaat bagi kehidupan peserta didik dengan memberikan rangsangan tugas, tantangan, memecahkan masalah, atau mengembangkan pembiasaan agar dalam dirinya tumbuh kesadaran bahwa belajar menjadi kebutuhan hidupnya. Ada baiknya setiap guru mengetahui tipe belajar setiap peserta didiknya, agar kegiatan pembelajaran yang diselenggarakan dapat mencapai tujuan secara efektif dan efisien. Pengetahuan tipe belajar siswa ini akan bermanfaat bagi guru dalam menerapkan model pembelajaran yang tepat [10].

Keaktifan peserta didik adalah salah satu prinsip utama dalam proses pembelajaran. Belajar yaitu berbuat atau melakukan, oleh sebab itu tidak akan ada kegiatan belajar tanpa aktivitas. Aktivitas peserta didik memiliki peranan penting dalam proses pembelajaran, pengalaman belajar hanya dapat diperoleh jika peserta didik aktif berinteraksi dengan lingkungan sekitarnya. Keaktifan peserta didik selama proses pembelajaran merupakan salah satu indikator dari adanya keinginan atau motivasi siswa untuk belajar [11]. Keaktifan siswa adalah suatu keadaan dimana peserta didik berpartisipasi secara aktif dalam pembelajaran. Dalam hal ini keaktifan peserta didik dapat dilihat dari cara peserta didik merespon pertanyaan atau perintah dari guru, mendengarkan dan memperhatikan penjelasan guru, berani mengemukakan pendapat, serta aktif dalam mengerjakan soal yang diberikan guru. 
Peran guru dalam pembelajaran matematika sangat penting. Pola penyampaian guru yang tidak terstruktur sehingga dalam pemahamannya siswa mengalami kesulitan dalam memahami materi. Pola tersebut yang membuat minat dan keaktifan siswa terhadap materi yang diajarkan kurang baik. Minat menurut [12] ialah kecenderungan yang bertahan lama untuk memperhatikan dan mengenang beberapa aktivitas. Seseorang yang berminat terhadap aktivitas akan memperhatikan aktivitas itu secara tetap dengan rasa senang. Sedangkan keaktifan adalah perilaku aktif dan kreatif siswa terhadap materi pembelajaran. Pembelajaran aktif adalah pembelajaran yang harus menumbuhkan suasana sedemikian rupa sehingga siswa aktif bertanya, mempertanyakan, dan mengemukakan gagasan. Salah satu model pembelajaran aktif yang dapat mengatasi permasalahan tersebut yaitu model Snowball Throwing. Model pembelajaran ini menggali potensi kepemimpinan siswa dalam kelompok serta keterampilan membuat-menjawab pertanyaan yang digabungkan melalui permainan imajinatif membentuk dan melempar bola salju [13]. Keaktifan siswa dalam kegiatan belajar merupakan cara untuk mengkonstruksi pengetahuan mereka sendiri. Siswa aktif dalam menciptakan pemahaman atas persoalan atau segala sesuatu yang mereka hadapi dalam proses pembelajaran [14]. Indikator keaktifan belajar siswa yaitu perhatian siswa dalam pembelajaran, kerjasama antar siswa dalam pembelajaran, terlibat dalam pemecahan masalah, kesiapan siswa dalam mengikuti pembelajaran dan mengemukakan pendapat atau ide.

[9] Wahyu Ratriningsih, dkk menyatakan bahwa kelebihan dari model pembelajaran snowball throwing adalah siswa akan dengan mudah untuk mendapatkan bahan pembicaraan karena adanya pertanyaan-pertanyaan yang ditulis pada kertas yang berbentuk bola, dapat meningkatkan kreatifitas belajar siswa karena terdapat unsur permainan, meningkatkan pemahaman materi yang dipelajari, saling memberikan pengetahuan. Dengan diharuskannya membuat sebuah pertanyaan, hal ini akan melatih kesiapan siswa dalam merumuskan pertanyaan dengan bersumber pada materi yang diajarkan. Selain itu, dengan terbiasanya dalam membuat pertanyaan maka dapat meningkatkan keberanian siswa dalam mengemukakan pertanyaan baik ke teman lain maupun guru. Siswa juga terlatih untuk menjawab pertanyaan dari temannya karena dalam pembelajaran ini mereka diberi kesempatan untuk menjawab pertanyaan yang dijawab tentunya dengan jawaban yang benar.

[1] Andi Tenriawaru mengungkapkan bahwa dengan memilih model snowball throwing diyakini dapat menghilangkan kendala-kendala yang dialami oleh siswa saat pembelajaran, karena model pembelajaran ini memberikan suatu pembelajaran yang menyenangkan, karena siswa diajak dan dibimbing belajar sambal bermain. Setelah menggunakan model pembelajaran tersebut siswa akan terlibat secara langsung dalam proses pembelajaran serta siswa dengan sendirinya akan menjadi sumber belajar untuk diri sendiri maupun kepada siswa lainnya. Model pembelajaran ini selain melatih kesiapan siswa, juga dapat meningkatkan kemampuan siswa dalam berkomunikasi serta berperan aktif dalam pembelajaran matematika.

Pemilihan model pembelajaran snowball throwing merupakan pemilihan model pembelajaran yang sangat tepat untuk diterapkan pada jenjang sekolah menengah pertama khususnya pada mata pelajaran matematika pada semua materi, karena model pembelajaran ini mampu melibatkan keaktifan siswa melalui permainan yang dilakukan. Permainan tersebut berupa menggulung dan melemparkan bola kertas yang berisi pertanyaan, yang apabila di lemparkan oleh sesama siswa seolah-olah bola tersebut seperti salju [15]. Setelah itu, siswa akan menjawab pertanyaan yang berada pada bola kertas sekaligus mempertanggungjawabkan jawabannya dengan mengoreksi jawaban yang menerima bola kertas tersebut. Sehingga diharapkan model pembelajaran snowball throwing dapat meningkatkan keaktifan siswa.

Pembelajaran dikatakan berhasil dan berkualitas apabila sebagian besar peserta didik terlibat secara aktif, baik fisik, mental maupun sosial dalam proses pembelajaran, selain menunjukkan kegairahan belajar yang tinggi, semangat belajar yang besar, dan rasa percaya pada diri sendiri. Berdasarkan hal tersebut, upaya guru dalam mengembangkan keaktifan belajar siswa sangatlah penting, sebab keaktifan belajar siswa menjadi salah satu penentu bagi keberhasilan pembelajaran yang dilaksanakan [16].

Berdasarkan uraian di atas, maka penulis bermaksud untuk melakukan suatu kegiatan penelitian dalam bentuk penelitian tindakan kelas dengan judul "Penerapan Model Pembelajaran Snowball Throwing untuk Meningkatkan Keaktifan Matematis Materi Lingkaran pada Siswa SMP". Penelitian ini bertujuan untuk mengetahui bahwa dengan penerapan pembelajaran snowball throwing dapat meningkatkan keaktifan belajar siswa pada mata pelajaran matematika mengenai materi lingkaran pada siswa kelas VII H SMPN 1 Ciruas. 


\section{METODE PENELITIAN}

Metode penelitian ini menggunakan penelitian tindakan kelas (PTK) atau classroom action research yang melibatkan refleksi berulang terdiri atas beberapa tahap, yaitu perencanaan (planning), tindakan (action), pengamatan (observasi), refleksi (reflection), perencanaan ulang dan seterusnya. Tahap-tahap tersebut disusun ke dalam siklus kegiatan. Metode penelitian tindakan kelas ini akan diadakan sebanyak dua siklus. Setiap siklus dilaksanakan dengan 2 kali pertemuan sesuai dengan perubahan yang ingin dicapai.

Penelitian ini dilaksanakan di SMP Negeri 1 Ciruas Kabupaten Serang semester genap tahun pelajaran 2019/2020, dengan subyek penelitian yang merupakan siswa kelas VIII H sebanyak 33 siswa. Obyek penelitian ini adalah model pembelajaran snowball throwing. Teknik pengumpulan data yang dilakukan yaitu (1) Observasi, dilakukan oleh peneliti dalam menilai keaktifan siswa. (2) Angket, dibagikan dan diisi oleh siswa untuk mengetahui respon keaktifan siswa dengan penerapan pembelajaran snowball throwing. (3) Dokumentasi, diperoleh dari hasil foto-foto selama kegiatan pembelajaran berlangsung. Instrumen yang digunakan untuk mengumpulkan data dalam penelitian ini yaitu lembar angket. Angket dilakukan sebanyak dua kali, pertama dilakukan pada pertemuan ke-1 siklus I dan yang kedua dilakukan pada pertemuan terakhir pada siklus II. Kemudia hasil instrumen tersebut dianalisis oleh peneliti, untuk mencari hasil skor sehingga dapat diketahui perbedaan persentase dari setiap siklusnya. Teknik analisis data yang dilakukan yaitu dengan menggunakan deskriptif kuantitatif, yaitu data yang telah dikumpulkan berupa angka.

Faktor-faktor yang diselidiki yaitu faktor proses dan faktor hasil. Faktor proses yaitu untuk melihat keterlaksanaan proses belajar mengajar yang antara lain kehadiran siswa, perubahan sikap siswa, dan keaktifan siswa dalam proses pembelajaran matematika melalui model pembelajaran snowball throwing, serta terjalinnya interaksi siswa dengan guru maupun siswa dengan siswa [1].

Untuk menganalisis kriteria keberhasilan siswa dalam penelitian ini, maka perlu diberikan pemaknaan terhadap skor yang dicapai oleh masing-masing siswa. Sehingga perlu dilakukan penyusunan pedoman penafsirannya mengacu pada pedoman penskoran yang dilakukan oleh Shinta Muning Salasih [17] dengan langkah sebagai berikut:

1) Menghitung skor terendah yang mungkin dicapai oleh masing-masing siswa. Skor terendah ini didapatkan dengan mengalikan skor terendah masing-masing aspek yang dinilai dikalikan dengan banyaknya aspek yang dinilai. Skor terendah dari penelitian ini yaitu 0 dan jumlah aspek yang dinilai adalah sebanyak 21 indikator. Maka total skor terendahnya adalah

$$
0 \times 21=0
$$

2) Menghitung skor tertinggi yang mungkin dicapai oleh masing-masing siswa. Skor tertinggi ini didapatkan dengan mengalikan skor tertinggi masing-masing aspek yang yang dinilai dikalikan dengan banyaknya aspek yang dinilai. Skor tertinggi dari penelitian ini yaitu 3 dan jumlah aspek yang dinilai adalah sebanyak 21 indikator. Maka total skor tertinggi adalah

$$
3 \times 21=63
$$

3) Menghitung selisih skor tertinggi dan terendah dengan cara skor tertinggi dikurangi dengan skor terendah. Maka hasilnya yaitu

$$
63-0=63
$$

4) Menentukan jumlah kategori yang akan digunakan untuk menafsirkan skor masing-masing siswa. Jumlah kategori sebaiknya sebanding dengan pedoman skor awal. Dalam penilaian lembar angket, jumlah kategorinya ada 4 yaitu, selalu (3), sering (2), jarang (1), tidak pernah (0). Maka peneliti menentukan jumlah kategorinya juga sebanyak 4 dengan kategori sangat tinggi, tinggi, sedang, rendah.

5) Menentukan rentang untuk masing-masing kategori, yaitu jumlah selisih skor tertinggi dengan skor terendah dibagi banyaknya kategori. Maka didapatkan rumus sebagai berikut: [6]

Rentangan $=\frac{\text { Skor Tertinggi-Skor Terendah }}{\text { Banyak Kategori }}=\frac{63}{0}=15,75$

Jadi rentangan untuk masing-masing kategori adalah 16. 
6) Menetapkan skor masing-masing kategori, dimana berdasarkan perhitungan di atas, banyaknya skor masing-masing yaitu 16 skor. Penetapan skor pada kategori dapat dimulai dari skor tertinggi sampai skor terendah, yaitu sebagai berikut:

$\begin{array}{ll}\text { Sangat Tinggi } & : 48-63 \\ \text { Tinggi } & : 32-47 \\ \text { Sedang } & : 16-31 \\ \text { Rendah } & : 0-15\end{array}$

Selanjutnya yaitu memberikan pemaknaaan atau penafsiran terhadap skor siswa sesuai dengan kategori atau interval di atas. Sementara untuk menghitung persentase keaktifan siswa yaitu sebagai berikut:

$$
\text { Persentase Keaktifan }=\frac{\text { Jumlah Skor Keaktifan Siswa }}{\text { Skor Maksimal }} \times 100 \%
$$

Keaktifan belajar siswa pada penelitian ini setelah diterapkannya model pembelajaran snowball throwing dapat dikatakan meningkat apabila hasil rata-rata persentase seluruh aspek yang diamati lebih dari 65\% [6]. Apabila dalam satu siklus saja hasil rata-rata sudah mencapai persentase $65 \%$, maka penelitian tersebut sudah dapat dikatakan meningkat. Sesuai dengan model McKernan dalam artikel Zetty [18] yaitu jika pada siklus kedua ternyata tindakan yang diberikan sudah dapat memecahkan masalah, maka penelitian dapat diakhiri. Sebaliknya jika penelitian belum dapat mencapai tujuan dan memecahkan masalah penelitian maka peneliti masuk pada siklus berikutnya.

\section{HASIL DAN PEMBAHASAN}

Penelitian ini dilakukan dalam dua siklus. Berdasarkan hasil penelitian yang telah dilakukan di SMP Negeri 1 Ciruas kelas VIII H pada hari Selasa, 10 Maret 2020 sampai Kamis 12 Maret 2020, menunjukkan bahwa terdapat peningkatan keaktifan belajar siswa setelah dilakukannya pembelajaran model snowball throwing. Peningkatan keaktifan siswa meliputi lima indikator dengan jumlah butir sebanyak 21 butir. Indikator-indikator tersebut yaitu (1) antusias siswa dalam mengikuti pembelajaran, (2) interaksi siswa dengan guru, (3) kerjasama kelompok, (4) keaktifan siswa dalam kelompok, (5) partisipasi siswa dalam menyimpulkan hasil pembelajaran.

Yulfika menjelaskan bahwa model pembelajaran snowball throwing baik diterapkan pada proses pembelajaran karena memiliki keunggulan yaitu dapat membuat siswa terlibat secara langsung pada proses pembelajaran [6]. Siswa mendapatkan penjelasan dari teman yang menjadi ketua kelompok. Siswa juga akan merasa lebih nyaman untuk belajar dan tidak malu-malu untuk bertanya karena siswa berdiskusi dengan teman sekelompoknya untuk membahas materi. Dengan dilakukannya penerapan pembelajaran model snowball throwing, maka siswa dilatih untuk bertanggung jawab, percaya diri, dan mampu bekerjasama dengan teman kelompoknya.

Siklus I dilaksanakan pada hari Selasa, 10 Maret 2020. Siklus I ini dilaksanakan sebanyak satu pertemuan. Jumlah siswa yang hadir adalah sebanyak 33 siswa. Penelitian ini dimulai pada pukul 10.00 WIB sampai pukul 12.00 WIB. Pada tahap tindakan siklus I ini, belum terlihat adanya keaktifan dalam diri siswa, karena pada saat pembelajaran berlangsung siswa masih enggan untuk bertanya dan terlihat malumalu saat ditanya oleh peneliti. Kemudian masih terdapat beberapa siswa yang terlihat sedang mengobrol dengan teman sebangkunya saat peneliti sedang memberikan materi pelajaran. Pada saat penelitian, masingmasing siswa menunjukkan perilaku yang berbeda-beda pada saat menerima pelajaran. Oleh sebab itu, maka hasil yang didapatkan juga akan berbeda. Untuk menganalisis nilai keaktifan siswa selama proses pembelajaran matematika pada materi lingkaran, maka diperlukan pemberian makna atas nilai yang telah dicapai oleh setiap siswa. Karena menggunakan skor, maka nilai siswa tercantum dalam beberapa interval berikut:

Tabel 1. Kategori nilai keaktifan siswa siklus I

\begin{tabular}{ccccc}
\hline No & Kategori & Sekor Keaktifan Siswa & Jumlah Siswa & Persentase \\
\hline 1 & Sangat Tinggi & $48-63$ & 4 & $12,12 \%$ \\
\hline 2 & Tinggi & $32-47$ & 21 & $63,64 \%$ \\
\hline 3 & Sedang & $16-31$ & 8 & $24,24 \%$ \\
\hline 4 & Rendah & $0-15$ & & $100 \%$ \\
\hline \multicolumn{2}{r}{ Jumlah } & & 33 & \\
\hline
\end{tabular}


Hasil dari tabel di atas menunjukkan bahwa keaktifan siswa pada siklus I yaitu terdapat siswa dengan kategori sangat tinggi yaitu sebanyak 4 siswa dengan persentase 12,12\%. Lalu siswa yang mendapatkan kategori tinggi yaitu sebanyak 21 siswa dengan persentase 63,64\%. Kemudian siswa yang mendapatkan kategori sedang sebanyak 8 orang dengan persentase $24,24 \%$.

Hasil siklus I, yakni dari hasil observasi peneliti, didapatkan bahwa hasil dari keaktifan siswa yaitu sebesar 45,88\% dan didapatkan bahwa jumlah skor keaktifan yang dicapai oleh keseluruhan siswa yaitu sebanyak 1240, dengan jumlah skor idealnya adalah 2079. Persentase keaktifan siswa berdasarkan hasil tersebut yaitu:

$$
\begin{aligned}
& \text { Persentase Keaktifan }=\frac{1240}{2079} \times 100 \% \\
& \text { Persentase Keaktifan }=59,64 \%
\end{aligned}
$$

Berdasarkan hasil di atas, dapat disimpulkan bahwa perlu dilakukan peningkatan aktivitas pada pertemuan selanjutnya walaupun pada tabel terdapat beberapa siswa yang mencapai kategori sangat tinggi, namun hasil persentase belum mencapai kriteria keberhasilan yang ditetapkan oleh peneliti, yaitu sebesar $65 \%$. Hal tersebut dapat disebabkan karena siswa belum mampu mengikuti pembelajaran dengan baik karena belum beradaptasi dengan model pembelajaran yang baru. Saat pembelajaran berlangsung, masih terdapat beberapa siswa yang belum sepenuhnya memperhatikan materi. Maka itu, diperlukan perbaikan pada pertemuan selanjutnya agar model pembelajaran snowball throwing terbukti dapat meningkatkan keaktifan siswa.

Berdasarkan hasil refleksi pada siklus I, bahwa peningkatan keaktifan belajar siswa belum mencapai kriteria yang telah ditetapkan oleh peneliti. Oleh sebab itu, maka perlu dilakukan perbaikan pada tahap pelaksanaan pada siklus II sehingga dapat mencapai kriteria peningkatan keaktifan siswa.

Siklus II dilaksanakan pada hari Kamis, 12 Maret 2020. Dilaksanakan pada pukul 12.45 WIB sampai dengan pukul 14.45 WIB dengan jumlah siswa sebanyak 33 orang. Pada tahap tindakan siklus II ini terdapat peningkatan keaktifan siswa. Pada pembelajaran, peneliti merangsang pertanyaan-pertanyaan kepada siswa dengan memainkan bola-bola kertas. Bola-bola tersebut berisi pertanyaan lalu di lemparkan kepada sesama siswa, setelah itu siswa menjawab pertanyaan yang berada pada kertas yang didapatkannya. Siswa dapat mempertanggungjawabkan pertanyaanya dengan berargumen apabila terdapat kekeliruan pada jawaban yang diberikan. Pada tahap ini juga siswa sudah berani untuk bertanya kepada peneliti tanpa ditanya terlebih dahulu oleh peneliti. Siswa juga terlihat lebih antusias dibandingkan dengan siklus I karena siswa sudah dapat menyerap dengan baik model pembelajaran yang diberikan oleh peneliti.

Berdasarkan hal tersebut menunjukkan bahwa keaktifan siswa sudah meningkat apabila dibandingkan dengan siklus I. Nilai siswa pada siklus II tercantum dalam beberapa interval berikut:

Tabel 2. Kategori nilai keaktifan siswa siklus II

\begin{tabular}{ccccc}
\hline No & Kategori & Sekor Keaktifan Siswa & Jumlah Siswa & Persentase \\
\hline 1 & Sangat Tinggi & $48-63$ & 11 & $33,33 \%$ \\
\hline 2 & Tinggi & $32-47$ & 22 & $66,67 \%$ \\
\hline 3 & Sedang & $16-31$ & & \\
\hline 4 & Rendah & $0-15$ & & $100 \%$ \\
\hline \multicolumn{7}{r}{ Jumlah } & & 33 & \\
\hline
\end{tabular}

Hasil dari tabel di atas menunjukkan bahwa keaktifan siswa pada siklus II yaitu terdapat siswa dengan kategori sangat tinggi yaitu sebanyak 11 siswa dengan persentase 33,33\%. Lalu siswa yang mendapatkan kategori tinggi yaitu sebanyak 22 siswa dengan persentase 66,67\%.

Pada hasil siklus II, didapatkan bahwa jumlah skor keaktifan yang dicapai oleh keseluruhan siswa yaitu sebanyak 1395, dengan jumlah skor idealnya adalah 2079. Persentase keaktifan siswa berdasarkan hasil tersebut yaitu:

Persentase Keaktifan $=\frac{1240}{2079} \times 100 \%$

Persentase Keaktifan $=59,64 \%$

Kriteria keberhasilan peningkatan keaktifan siswa yang ditetapkan oleh peneliti yaitu apabila mampu mecapai skor sebesar 65\%. Pada siklus II didapatkan hasil dari angket terhadap peningkatan keaktifan siswa yang menunjukkan hasil persentase siswa keseluruhan yaitu sebesar $67,09 \%$. Berdasarkan hal tersebut, 
maka didapatkan bahwa dengan menggunakan model snowball throwing dapat meningkatkan keaktifan siswa. Pada siklus I menghasilkan persentase sebesar 59,64\% dengan jumlah 33 siswa. Maka didapatkan bahwa peningkatan keaktifan siswa dari siklus I ke siklus II yaitu sebesar 7,45\%.

Dapat disimpulkan bahwa pada siklus II peningkatan keaktifan siswa telah mencapai kriteria keberhasilan yang ditetapkan oleh peneliti. Oleh karena itu, penelitian tindakan kelas ini tidak dilanjutkan pada siklus selanjutnya karena sudah mecapai kriteria yang ditetapkan oleh peneliti. Sehingga penelitian ini telah dianggap berhasil meningkatkan keaktifan siswa dengan model pembelajaran snowball throwing. bawah ini:

Hasil pengamatan keaktifan siswa secara keseluruhan pada setiap siklus dapat dilihat pada tabel di

Tabel 3. Kategori nilai keaktifan siswa siklus II

\begin{tabular}{cccc}
\hline Siklus & Jumlah Siswa & Persentase & Kriteria Keberhasilan \\
\hline Siklus I & 33 & $59,64 \%$ & \multirow{2}{*}{$65 \%$} \\
\hline Siklus II & 33 & $67,09 \%$ & \\
\hline
\end{tabular}

Untuk lebih jelasnya bagaimana peningkatan keaktifan dari siklus I dan siklus II dapat dilihat pada grafik di bawah ini:

Peningkatan Keaktifan Siswa pada Setiap Siklus

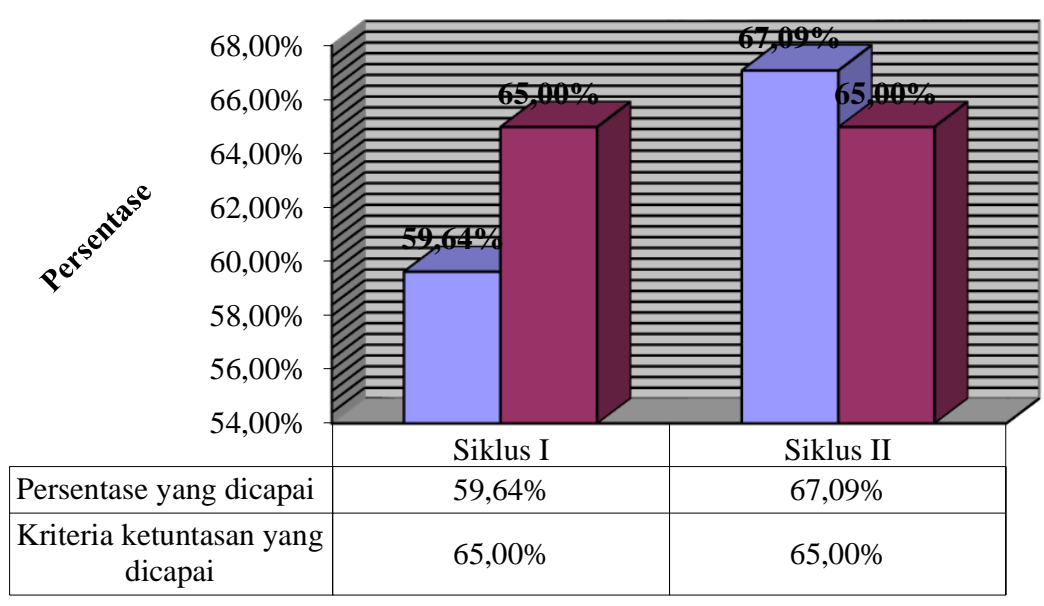

Grafik 1. Grafik Penigkatan Keaktifan Siswa pada Siklus I dan Siklus II

Berdasarkan Grafik 1 di atas menunjukkan bahwa terdapat peningkatan keaktifan siswa dari siklus I ke siklus II. Keberhasilan dalam penerapan pembelajaran dengan menggunakan model snowball throwing untuk meningkatkan keaktifan siswa pada penelitian ini tercapai pada penerapan siklus II. Peningkatan keaktifan siswa pada siklus II yaitu sebesar $67,09 \%$ dari standar keaktifan yang telah ditetapkan oleh peneliti yaitu sebesar 65\%. Jika pada siklus kedua ternyata tindakan yang diberikan sudah dapat memecahkan masalah, maka penelitian dapat diakhiri. Sebaliknya jika penelitian belum dapat mencapai tujuan dan memecahkan masalah penelitian maka peneliti masuk pada siklus berikutnya [18].

\section{KESIMPULAN}

Berdasarkan rumusan masalah dan hasil pembahasan yang diperoleh peneliti, maka dapat diperoleh kesimpulan sebagai berikut:

1. Penerapan model pembelajaran snowball throwing mampu meningkatkan keaktifan siswa kelas VIII H SMP Negeri 1 Ciruas pada mata pelajaran Matematika yaitu dengan adanya peningkatan persentase keaktifan siswa pada siklus I ke siklus II, yakni siklus I dari hasil observasi peneliti, didapatkan bahwa hasil dari keaktifan siswa yaitu sebesar $45,88 \%$ dan dari skor angket adalah sebesar 59,64\% dan siklus II mencapai nilai $67,09 \%$ dari standar keaktifan yang telah ditetapkan peneliti yaitu sebesar $65 \%$. Sehingga didapatkan selisih persentase dari siklus I ke siklus II yaitu sebesar 7,45\%. 
2. Hasil dari kategori keaktifan siswa didapatkan bahwa pada siklus I terdapat 4 siswa dengan kategori sangat tinggi dengan persentase $12,12 \%$, lalu terdapat 21 siswa dengan kategori tinggi dengan persentase $63,64 \%$, serta terdapat 8 siswa dengan kategori sedang dengan persentase 24,24\%. Kemudian terdapat peningkatan hasil keaktifan siswa pada siklus II dimana terdapat 11 siswa dengan kategori sangat tinggi dengan persentase 33,33\% dan terdapat 22 siswa dengan kategori tinggi dengan persentase $66,67 \%$

\section{DAFTAR PUSTAKA}

[1] Tenriawaru, A. "Upaya Meningkatkan Hasil Belajar Matematika Siswa Sma Melalui Model Pembelajaran Kooperatif Tipe Snowball Throwing," Indiktika J. Inov. Pendidik. Mat., vol. 1, no. 2, p. 181, 2019, doi: 10.31851/indiktika.v1i2.3191.

[2] Yuliati, "Efektifitas Penggunaan Model Kooperatif Tipe Snowball Throwing Untuk Meningkatkan Hasil Belajar Siswa Pada Materi Sistem Pertidaksamaan Linear Di Kelas Xi-Is-2 Sma Negeri 7 Banda Aceh,” J. Peluang, vol. 3, no. 2, pp. 65-78, 2016.

[3] Palinussa A. L. dan Thaib, A. "Mengkaji Perbedaan Kemampuan Matematis Siswa Kelas Viii Smp Dengan Menggunakan Model Pembelajaran Kooperatif Tipe Think Pair Share (Tps) Dan Model Pembelajaran Konvensional Ditinjau Dari Level Sekolah," BAREKENG J. Ilmu Mat. dan Terap., vol. 14, no. 1, pp. 023030, 2020, doi: 10.30598/barekengvol14iss1pp023-030.

[4] Yuliany, N. "Hubungan Motivasi dan Hasil Belajar Siswa Kelas XI MAN Model Makassar," Edumatika J. Ris. Pendidik. Mat., vol. 2, no. 1, p. 23, 2019, doi: 10.32939/ejrpm.v2i1.227.

[5] Ayukmartina, F., Sudjadi, A. A.dan Purnami, A. S. "Matematika Melalui Model Pembelajaran Think Pair Share Siswa Kelas Viid Smp N 1 Srumbung Kabupaten Magelang," UNION J. Pendidik. Mat., vol. 2, no. 1, pp. 97-102, 2014.

[6] Arifin, Y. "Penerapan Model Pembelajaran Snowball Throwing untuk Meningkatkan Keaktifan dan Hasil Belajar Siswa Kelas XI TKR 1 pada Mata Pelajaran Pemeliharaan Sains dan Pemindah Tenaga (PSPT) di SMK Ma'ruf 1 Wates," Universitas Negeri Yogyakarta, 2018.

[7] Talakua, M., Ratumanan, T. G. dan Tamalene, H. "MENGGUNAKAN MEDIA SWISHMAX DAN TANPA SWISHMAX PADA MATERI OPERASI HITUNG PECAHAN DI KELAS VII SMP NEGERI 3 AMBON The Comparison of Student Learning Results Using Swishmax and Without Swishmax Media in Fraction Counting Operation Materials in Class VII SMP," BAREKENG J. Ilmu Mat. dan Terap., vol. 14, no. 1, pp. 31-38, 2020.

[8] Hasan, H. "Kendala Yang Dihadapi Guru Dalam Proses Belajar Mengajar Matematika Di Sd Negeri Gani Kabupaten Aceh Besar," J. Pesona Dasar, vol. 1, no. 4, pp. 40-51, 2017.

[9] Ratriningsih, W., Sapti, W. dan Mujiyem, I. "Meningkatkan Keaktifan Belajar Siswa Melalui Model Pembelajaran Snowball Throwing Dengan Alat Peraga," EKUIVALEN - Pendidik. Mat., vol. 7, no. 3, pp. 240 245, 2014.

[10] Anggraeni V. dan Wasitohadi, W. "Upaya Meningkatkan Keaktifan Dan Hasil Belajar Matematika Siswa Kelas 5 Melalui Model Pembelajaran Kooperatif Tipe Teams Games Tournament (Tgt)Di Sekolah Dasar Virgo Maria 1 Ambarawa Semester Ii Tahun Pelajaran 2013 2014," Satya Widya, vol. 30, no. 2, p. 121, 2014, doi: 10.24246/j.sw.2014.v30.i2.p121-136.

[11] Alimuddin, H. "Pengaruh Keaktifan Belajar Siswa Melalui Penerapan Model Pembelajaran Kooperatif Tipe Team Assisted Individualization (Tai) Terhadap Hasil Belajar Matematika Siswa Kelas Vii Smp Negeri 4 Satap Bungoro," HISTOGRAM J. Pendidik. Mat., vol. 1, no. 1, p. 61, 2017, doi: 10.31100/histogram.v1i1.182.

[12] Zaeni, A., Sulistyaningsih, D. dan Suprayitno, I. J. "KEEFEKTIFAN MODEL PEMBELAJARAN SNOWBALL THROWING DENGAN PENDEKATAN KONTEKSTUAL TERHADAP KEMAMPUAN Berdasarkan uraian diatas penelitian ini bertujuan untuk mengetahui efektifitas model pembelajaran Snowball Throwing dengan pendekatan kontekstualterhadap ke," pp. 530-536, 2015.

[13] Susanti, K. A., Suadnyana, I. N. dan Zulaikha, S. "Pengaruh Model Snowball Throwing Berbantuan Media Konkret terhadap Hasil Belajar IPA Kelas V SD Gugusi Gusti Ngurah Rai Denpasar," e-Journal Mimb. PGSD Univ. Ganesha, vol. 2, no. 1, pp. 1-10, 2014.

[14] Putri, F. E., Amelia, F. dan Gusmania, Y. "Hubungan Antara Gaya Belajar dan Keaktifan Belajar Matematika Terhadap Hasil Belajar Siswa," Edumatika J. Ris. Pendidik. Mat., vol. 2, no. 2, p. 83, 2019, doi: 10.32939/ejrpm.v2i2.406.

[15] Elferasari, A. "Model Snowball Throwing Untuk Meningkatkan Motivasi Dan Hasil Belajar Matematika Kelas Vii-a Smp Kartika Xii-1," UNION J. Ilm. Pendidik. Mat., vol. 5, no. 2, pp. 169-174, 2017, doi: 10.30738/.v5i2.1239.

[16] Setiawan J. A. dan Sujadi, A. "UPAYA MENINGKATKAN KEAKTIFAN DAN PRESTASI BELAJAR MATEMATIKA DENGAN SNOWBALL THROWING SISWA KELAS VII C SMP NEGERI 2 KOKAP 
KULON PROGO,” UNION J. Pendidik. Mat., vol. 3, no. 3, pp. 297-302, 2015.

[17] Salasih, S. M. "Meningkatkan Keaktifan Belajar Siswa Menggunakan Model Quantum Teaching pada Materi Bangun Ruang di Kelas V SD Negeri Sangon Kokap Kulon Progo,” Universitas Negeri Yogyakarta, 2013.

[18] Ni'mah, Z. A. "URGENSI PENELITIAN TINDAKAN KELAS BAGI PENINGKATAN PROFESIONALITAS GURU ANTARA CITA DAN FAKTA,” Realita, vol. 15, no. 2, pp. 1-22, 2017. 
